\title{
EFFECT OF COOLING RATE DURING CENTRIFUGAL CASTING ON THE CREEP RUPTURE STRENGTH OF $13 \%$ Cr STEEL
}

\author{
Mohamed O. ALNAIS \\ College of Technology at Hail, KSA
}

\begin{abstract}
It is well known that $13 \% \mathrm{Cr}$ steel is one of the most economic stainless steels. It is, however, inferior to austenitic stainless steels in creep rupture strength above $600^{\circ} \mathrm{C}$.

Therefore, an attempt has been made to improve the creep rupture, strength of $13 \% \mathrm{Cr}$ steel. This work is principally concerned with the investigation of the influence of the cooling rate during centrifugal casting on the creep rupture strength of $13 \% \mathrm{Cr}$ steel.

The results obtained are summarized as follows:

- The creep strength of $13 \% \mathrm{Cr}$ steel is improved by increasing cooling rate during centrifugal casting.

- The higher cooling rate promotes: large sizes of columnar structures and fine dispersion of precipitates. These are shown to have a beneficial effect on the creep strength of $13 \%$ steel.
\end{abstract}

\section{INTRODSUCTION:}

Pressure containing components for power generating plant must operate for considerable periods at elevated temperatures. Design approaches for these components generally involve the application of an allowable stress $\sigma_{a}$ which permits calculation of a minimum wall thickness (mwt) as:

$$
\mathrm{mwt}=\mathrm{PD} /\left(2 \sigma_{\mathrm{a}} \mathrm{E}+\mathrm{P}\right)
$$

Where $D$ is the outside diameter, $P$ is the internal pressure, and $E$ is an efficiency factor. Values of the allowable stress for creep applications are determined from extrapolating the appropriate material's uniaxial creep or creep-rupture data. However, safety factors are applied due to uncertainties involved with this approach.

Manuscript received from Dr. Mohammad Othman Alnais

Accepted on : 26/2/2001

Engineering Research Journal Vol 24,No 2, 2001 Minufiya University, Faculty of Engineering, Shebien El-Kom, Egypt, ISSN 1110-1180 
Short-term uniaxial creep rupture data can, in general, be described by a powerlaw dependence on stress. Simple extrapolation of this information is known to overestimate longterm lifetimes $/ 1 /$. The use of parametric techniques, e.g., the Larson-Miller procedure $/ 2 /$ allows data extrapolation of only approximately three times the longest rupture life $/ 3 /$.

The application of finite element stress analysis technique requires a more detailed material description. To provide engineers with material information, many methods of describing strain/time behavior have been suggested $/ 4 /$.

Recently, the $\theta$ projection concept has been suggested which considers creep strain $e$ to be the sum of two competing processes as follows $/ 5 /$.

$\varepsilon=\theta_{1}\left(1-\exp .-\theta_{2} t\right)+\theta_{3}\left(\exp . \theta_{4} t-1\right)$

Where $\theta 1$ and $\theta r$ define the primary or decaying strainrate component and $\theta 3$ and $\theta 4$ describe the tertiary or accelerating strain rate component of the creep curve.

Extrapolation of $\theta$ parameters for long times has been applied for $1 / 2 \mathrm{Cr}-1 / 2$ Mo-1/4 V ferritic steel at $565^{\circ} \mathrm{C} / 6 /$.

The factors affecting tube life operating under creep conditions have been illustrated in Fig. 1.

\begin{tabular}{|l|l|l|l|}
\hline No. & $\begin{array}{l}\text { Temperature-Dependent } \\
\text { Material Properties }\end{array}$ & \multicolumn{1}{|c|}{ Tube Size } & Operating Conditions \\
\hline 1 & Thermal conductivity & Diameter & Temperatures \\
\hline 2 & Thermal expansion & Wall thickness & Pressures \\
\hline 3 & Elastic modulus & & Type of working cycles: \\
\hline 4 & Poisson's ratio & & $\begin{array}{l}\text { a-heating rate. } \\
\text { b- duration. } \\
\text { c-cooling rate }\end{array}$ \\
\hline 5 & Stress-rupture life & & Number of cycles \\
\hline 6 & Creep response & & \\
\hline
\end{tabular}

Fig. (1): Factors affecting tube life under creep conditions.

Creep deformation behavior can be described by some sets of equations so that the creep strain accumulated during any time interval at a specific stress and temperature can be readily calculated. This is one aspect of developing constitutive equation for creep analysis.

A number of equations have been given in the literatures $/ 7 \& 8 \%$.

Creep damage leading to failure in ferritic steel at service operating conditions results from $/ 9 /$ :

i) Structural coarsening leading to a continuous reduction in creep strength during exposure.

ii) Intergranular creep cavitations. 
Both processes normally occur simultaneously; the prevalence of either is determined by the initial state and purity in addition to conditions of stress and: temperature.

In this work an attempt was made to improve the creep rupture strength of $13 \%$ Cr steel.

The present work investigated the effect of cooling : rate during centrifugal casting of $13 \% \mathrm{Cr}$ steel on the creep rupture strength. Variations in cooling rates during solidification were obtained by using a specially designed laboratory scale centrifugal casting machine, by changing the rotating speed, and by using different types of ingot moulds:

\section{EXPERIMENTAL PROCEDURE:}

Four heats of $5 \mathrm{Kg}$ each were air-melted in $20 \mathrm{KVA}$ high frequency induction furnaces; the chemical composition of the heats cast under different cooling rates is shown in Table 1. Two types of moulds were employed (graphite \& copper); in addition, the laboratory scale centrifugal casting machine was designed to give two different rotating speeds, 1400 and 1700 r.p.m. Corresponding to $50 \mathrm{~g}$ and $100 \mathrm{~g}$ respectively, where $\mathrm{g}$ is the gravity acceleration. The dimensions of the centrifugally cast tubes were $120 \mathrm{~mm}$ length, $100 \mathrm{~mm}$ outside diameter and $60 \mathrm{~mm}$ inside diameter.

An alumel-chromel thermocouple was inserted in the mould wall to touch the outer surface of the cast tube and the cooling rate during centrifugal casting was measured.

Table. (1): Chemical composition of $13 \% \mathrm{Cr}$ steel with the cooling rate according to casting condition

\begin{tabular}{|c|c|c|c|c|c|c|c|c|c|}
\hline \multirow[b]{2}{*}{ Specimen } & \multicolumn{2}{|l|}{$\begin{array}{l}\text { Casting } \\
\text { condition }\end{array}$} & \multicolumn{6}{|c|}{ Chemical composition (wt.\%) } & \multirow[b]{2}{*}{$\begin{array}{l}\text { Coolin } \\
\text { g rate } \\
{ }^{\circ} \mathrm{C} / \mathrm{min}\end{array}$} \\
\hline & $\begin{array}{l}\text { Mould } \\
\text { Type }\end{array}$ & $\begin{array}{l}\text { Cen } \\
\text { t. } \\
\text { For } \\
\text { ce }\end{array}$ & C & Mn & $\mathrm{Cu}$ & $\mathrm{Ni}$ & $\mathrm{Cr}$ & Mo & \\
\hline A & Graphite & $50 \mathrm{~g}$ & 0.06 & 0.42 & 0.15 & 0.39 & $\begin{array}{l}13 . \\
0\end{array}$ & $\begin{array}{l}0.1 \\
2\end{array}$ & 180 \\
\hline B & Graphite & $\begin{array}{l}100 \\
\mathrm{~g}\end{array}$ & 0.08 & 0.67 & 0.12 & 0.42 & $\begin{array}{l}13 . \\
4\end{array}$ & $\begin{array}{l}0.2 \\
2\end{array}$ & 370 \\
\hline $\mathrm{C}$ & Copper & $50 \mathrm{~g}$ & 0.07 & 0.53 & 0.20 & 0.53 & $\begin{array}{l}13 . \\
6\end{array}$ & $\begin{array}{l}0.1 \\
0\end{array}$ & 400 \\
\hline $\mathrm{D}$ & Copper & $\begin{array}{l}100 \\
\mathrm{~g}\end{array}$ & 0.05 & 0.73 & 0.11 & 0.48 & $\begin{array}{l}13 . \\
2\end{array}$ & $\begin{array}{l}0.2 \\
8 \\
\end{array}$ & 810 \\
\hline
\end{tabular}

The creep rupture test specimens were machined longitudinally from the wall section of each centrifugally cast tube.

Creep tests were conducted on simple lever-arm creep machines accurate to within $0.05 \%$ load. The loading system incorporated a series of universal joints in order to reduce axial bending in the specimens due to non - axiality of loading. Tests were carried in air and the specimens were heated in a 
resistance furnace controlled by proportional temperature controller to $+10 \mathrm{C}$ along the gauge length. Cylindrical specimens $(6.6 \mathrm{~mm}$ dia. $\times 35 \mathrm{~mm}$ gauge length) had ridges at the ends of gauge length for attaching the extensometer. Extension was determined by means of an electrical LVDT transducer giving a strain sensitivity of $5 \times 10^{-5}$.

The creep rupture tests were conducted at 600,700 and $800 \circ \mathrm{C}$ for time periods extending up to $3000 \mathrm{hr}$.

\section{RESULTS AND DISCUSSION:}

The calculated results of the measured cooling rates during the solidification of the centrifugally cast tubes are shown in Table 1. The table shows a wide variation in the cooling rates depending upon the type of mould employed and the rotating speed of the centrifugal casting machine. These variations are attributed mainly to the heat conductivity of the mould material as well as to the rate of cooling of the mould surface during rotation. The macrostructure of the cross section of the cast tubes demonstrated the typical structure of an outer layer of chill crystals, then the columnar grains varying in their length and width (according to cooling rate) and the equiaxed grains along the inner side. Fig. 2 shows the variations of the size of columnar grains in terms of $L$ and $D$ (where $\mathrm{L}$ is the length of column and $\mathrm{D}$ is its width) with the respective cooling rate.

From which, $\mathrm{L}$ and $\mathrm{D}$ increase with increasing cooling rate. These results seem to be inconsistent with the well-known studies on: $0.6 \% \mathrm{C}$ steel $/ 10 / \mathrm{Al}$-alloys and $\mathrm{Cu}$-alloys $/ \mathrm{j} \% /$ which say that the lower the cooling rate, the larger the grain size. However, the latter is concerned with "static" casting conditions while in centrifugal casting many other factors interact together and naturally the result might be different. Quantifying the latter indicator remains for future work. The x-ray diffraction analysis of the electrolitically extracted residues shows that the fast cooling rate tube (D) contained $(\mathrm{Cr}, \mathrm{Fe})_{23} \mathrm{C}_{6}$ and $\mathrm{Cr}_{2} \mathrm{~N}$, while the residues of the slow cooling rate tube $(\mathrm{A})$ contained a considerable amount of $(\mathrm{Cr}, \mathrm{Fe})_{7} \mathrm{C}_{3}$.

The creep rupture tests of each tube at 600,700 , and $800{ }^{\circ} \mathrm{C}$ are shown in Fig. 3. Examination of the data presented in the figure reveals a number of items of interest regard $\mathrm{mg}$ the effect of different cooling rates. For example, at $600^{\circ} \mathrm{C}$, the creep rupture strength does not show any remarkable change with increasing cooling rate, while at higher temperature, $700^{\circ} \mathrm{C}$, and the creep rupture strength gradually increased with the increase in cooling rate. With a further increase in the test temperature to $800^{\circ} \mathrm{C}$, the creep rupture strength of the high cooling rate tube (D) is approximately twice the creep rupture strength of the low cooling rate tube (A).

The creep rupture data are plotted to give the Larson-Miller parameter master curves for $\mathrm{A}$ and $\mathrm{D}$ specimens as in Fig. 4.

Again this confirms that with higher temperatures and prolonged times, the creep rupture strength increases with the increase of cooling rate during centrifugal castings. 
Several microstructure variables can influence the creep rupture strength of 13 $\% \mathrm{Cr}$ steel. The most important of these, which improve the creep strength with increasing, cooling rate is:

i) Solid solution strengthening,

ii) Dispersion hardening,

iii) Dislocation density, and

iv) Grain size \& grain morphology.

Regarding the first factor, it was found $/ 14 /$ that steel with a higher cooling rate of solidification, contained in its ferritic matrix dissolved carbon about $0.06 \mathrm{wt}$. $\%$ higher than that in steel with a low cooling rate. This is in agreement with that quoted for Al-Fe alloys $/ 11 \%$.

Increasing cooling rate during centrifugal casting led to a fine dispersion of $(\mathrm{Cr}$, $\mathrm{Fe})_{23} \mathrm{C} 6$ and $\mathrm{Cr} 2 \mathrm{~N}$ precipitates. Strong interactions between dislocations and these precipitates are quite possible indicating that dispersion hardening was prominent in determining creep strength.

Honeycombe/13/ has reviewed the direct evidence for the nucleation of alloy carbide and nitride particles at the $\gamma-\alpha$ interfaces during transformation of austenite.

The particles formed during interphase precipitation, or in ferrite after the phase transformation, can be very small, on the order of $5 \mathrm{~nm}$, and are therefore very effective as strengthening agents $/ 14 /$. The spacing of the precipitate planes decreases as the cooling rate increases $/ 15 /$.

In addition, Sidey $/ 16 /$ has shown that the secondary creep behavior of $1 \mathrm{Cr}$ Mo-V steel with a microstructure consisting of $10 \%$ bainite and $90 \%$ ferrite can be explained in terms of recovery controlled creep. The rate could be expressed in terms of the following equation:

$$
\epsilon^{0}=\mathrm{A}\left(\sigma_{\mathrm{a}}-\sigma_{0}\right)^{3.5} \exp (-240000 / \mathrm{RT}) \ldots(3)
$$

Where $A$ is a constant, $\sigma_{a}$ is the applied stress, and $\sigma_{0}$ is the friction stress introduced by the VC particle dispersion, which opposes dislocation motion, and which is additive to the normal resistance of the matrix to dislocation flow. There is no reason to suspect that the above equation does not apply to the creep of $13 \% \mathrm{Cr}$ steel studied in the present work. Thus, increasing cooling rate during centrifugal casting should result in a higher friction stress, a0l due to the finer dispersions of alloy carbides and nitrides.

In the examined range of test temperatures, no coalescence of the precipitated particles has been observed. Thus, fine dispersions of the precipitates, resulting from higher cooling rates during solidification (together with solid solution strengthening), are considered as affective means for improving the creep rupture strength of $13 \% \mathrm{Cr}$ steel. The retardation of coalescence of precipitated carbides and nitrides can be an important factor for ensuring high temperature creep rupture strength. In addition, the observed difference for 
the high creep.rupture strength can be attributed to the variation in the as-cast structure. (grain size and grain morphology) as a result of employing different cooling rates.

However, the reason why the larger size of columnar grains displays much better creep rupture strength (specimen $D$ ) can be interpreted to the interparticle spacing of the precipitates. :The latter was found to be smaller for the tubes with a large columnar size, which would prevent deformation and fracture by creep more effectively: than those in-the smaller columnar size structure (specimen A).

\section{CONCLUSIONS:}

Attempt has been made to improve the creep rupture strength of $13 \% \mathrm{Cr}$ steel. Four heats of $13 \% \mathrm{Cr}$ steel, $5 \mathrm{~kg}$ each, were centrifugally cast under different cooling rates.

The results obtained are summarized as follows:

1) The creep rupture strength is generally improved by accelerating the rate of cooling during casting.

2) Variation in the cooling rate during centrifugal casting, by employing two different types of moulds and different centrifugal forces, resulted in a considerable change of the size of precipitated particles and of the as-cast structure.

3) In the examined range of test temperatures $\left(600,700\right.$, and $\left.800^{\circ} \mathrm{C}\right)$ no coalescence of the precipitated carbides and nitrides has been observed. The fine dispersion of precipitated particles as well as solid solution strengthening, resulting from higher rates of cooling, can be an important factor for ensuring high creep rupture strength.

4) The higher cooling rate promotes a large size of columnar structure, which has a beneficial effect on the creep rupture strength. This effect can be attributed to the smaller interparticle spacing of the precipitates formed at the boundaries of the large grains and will be effective in preventing deformation and fracture by creep. In addition, cavities will have less chance to be condensed at grain boundaries.

Consequently, microcracks formation and their linking up to form macrocracks will be highly reduced.

5) It is proposed to study the effect of Mo and V additions on long-term creep rupture strength of $13 \% \mathrm{Cr}$ steel under rapid rates of solidification.

\section{REFERENCES:}

1. R.F.Johnson and F.Glen Proceeding of the conference on Creep Strength of Steel and High-Temperature Alloys, Metal Society, London (1994) P. 37.

2. F.R.Larson and J.Miller, ASME Trans. 74 (1952) P. 765. 
3. Standard Practice for Conducting Creep ; Creep-Rupture and StressRupture Tests of Metallic Materials, Annual Book of ASTM Standard, Vol. 12.01 (1996) P.E.139.

4. Y.N.Rabotnov, Creep Problems in Structural Members, Applied Mathematics and Mechanics Series, Vol. 17,North Holland, Amsterdam (1989) P.210.

5. R.W. Evans, J.D.Parker and B.Wilshire, Recent Advances in Creep and Fracture of Engineering Materials and Structures, Pineridge Press. Swansea, UK (1998), P.135.

6. R.W.Evans and B.Wilshire, Creep of Metals and Alloys, The Inst. of Metals, London,UK (1995),P.150.

7. C.E.Pugh, Advances in Design for Elevated Temperature Environments,eds.S.Y.Zamirk and R.I.Jetter,ASME (1995), 10.

8. J.B.Conway,Stress-Rupture Parameters:Origin,Calculation and Use. Gordon and Breach,N.Y.(1969).

9. P.Wiswanathan,J.of Pressure Vessel Technology,117 (1995) 218.

10. K.Schwerdtfeyer, Arch. Fur Eisenhuttenwesen 644 (1993) 6, 411.

11. E.Schurmann and B.Prinz, Arch.fur Eisenhuttenwesen 56(1985) 911.

12. H.Vohse, Dr.Ing.Thesis,Bergakademie,Freiberg (1990).

13. R.W.K.Honycombe, Metal.Trans. A,7A: (1967) 915.

14. A.T.Davenport and Honeycombe, Proc. Roy.Soc.(London)A322 (1971) 191.

15. J.M.Gray and R.B.Yeo, Trans.Am.Soc.Met. 61 (1968) 255.

16. D.Sidey, Met.Trans. 7A (1977) 1785. 


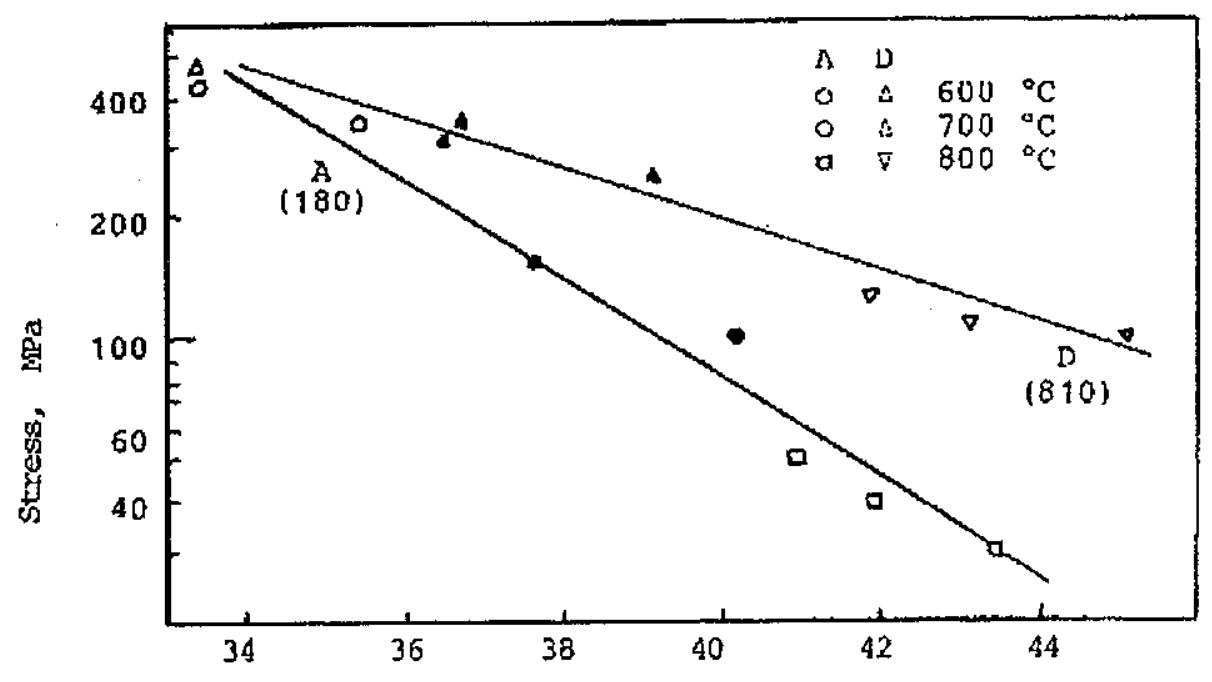

Fig. (2): The variation in length (L) and width (D) of the columnar structure with cooling rate.

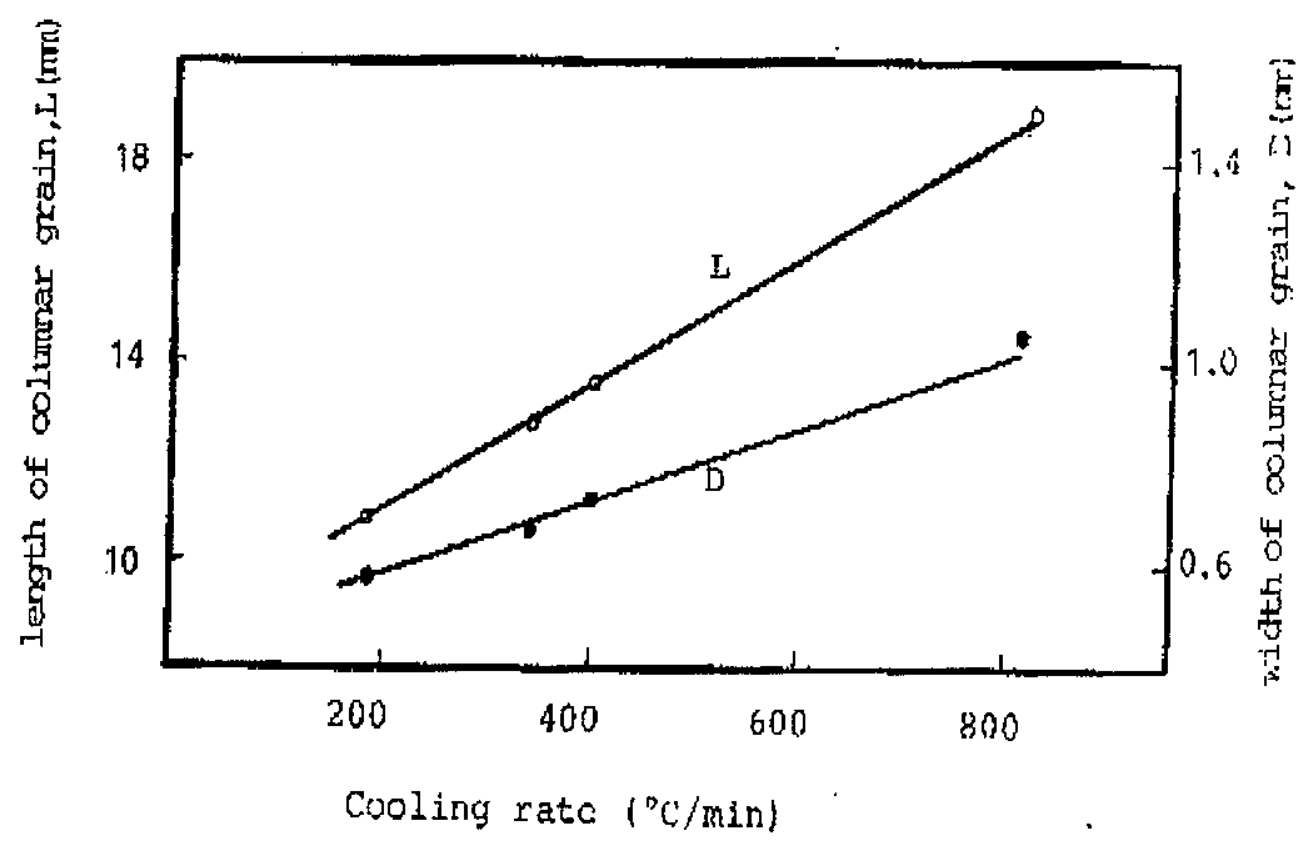

Fig. (4): The Larson-Miller Parameter (L.M.P) master curves.

(Cooling rate during casting in ${ }^{\circ} \mathrm{C} / \mathrm{min}$ ). 

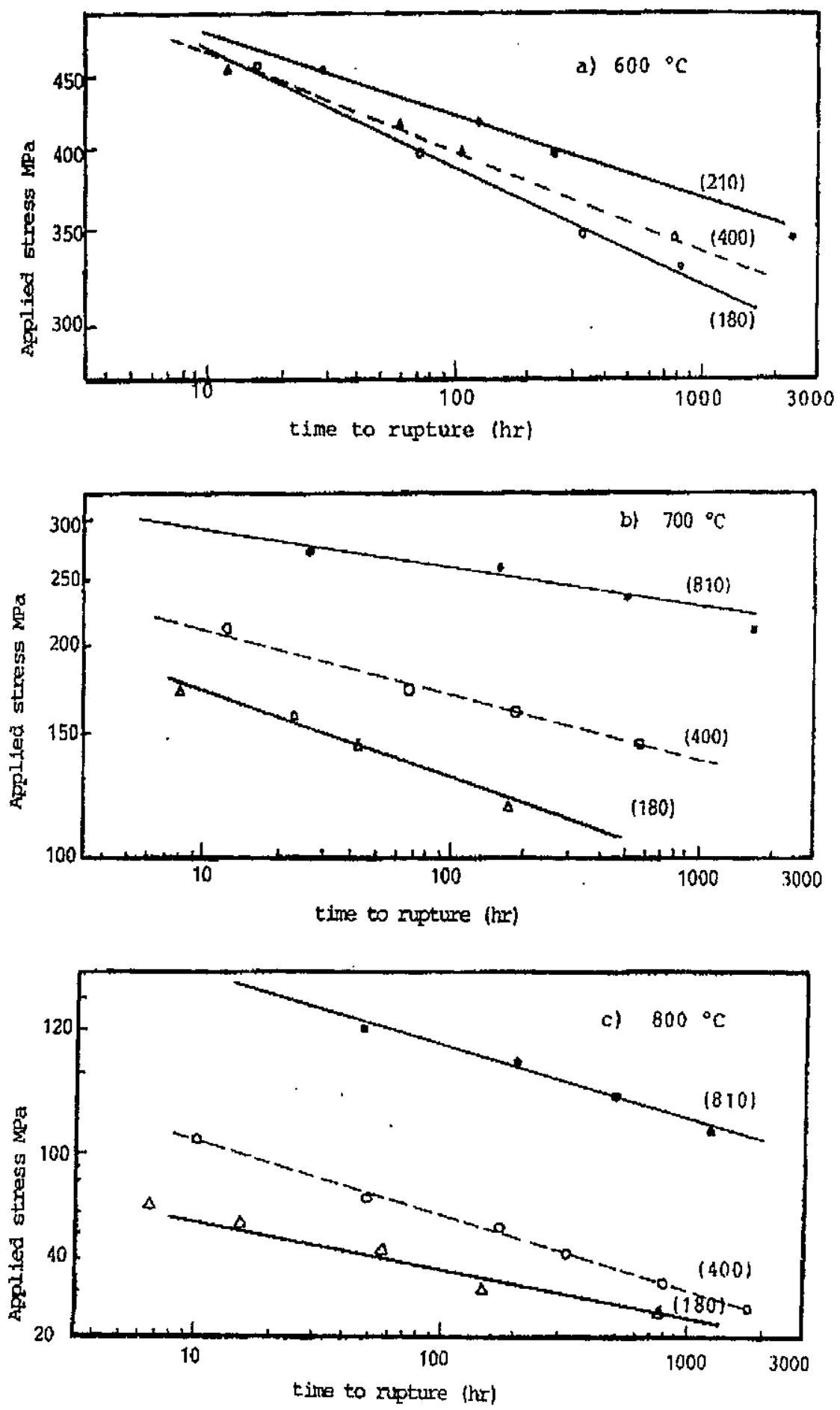

Fig. (3): Creep rupture tests at $600^{\circ} \mathrm{C}$ a), $700^{\circ} \mathrm{C}$ b), and $\left.800^{\circ} \mathrm{C} \mathrm{c}\right)-($ Cooling rate during casting in ${ }^{\circ} \mathrm{C} / \mathrm{min}$ ). 
تأثير معدل التبريد أثناء سباكة

الطرد المركزي علي مقاومة إنهيار

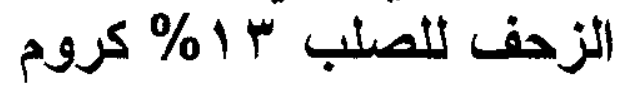

\section{محمد عثنماز النجيبسر}

\section{الكلية التقنية بحائل - المملكة العربية السعودية}

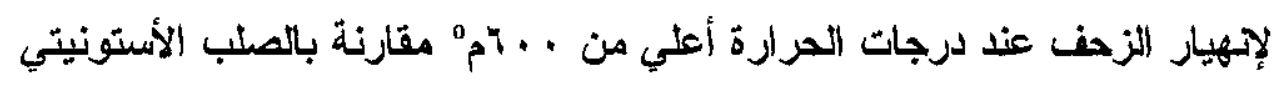

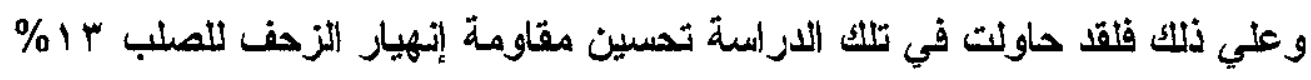

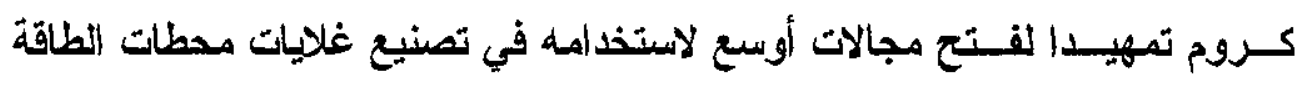

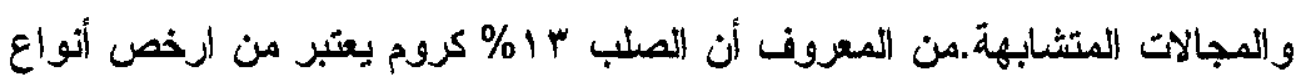
الصلب إستانلس ... لكنه أقل متانة

ولإجــاز هــذه المهاة تم استخدام قلبين للصلب من النحاس والجرافيت مع ماكينة

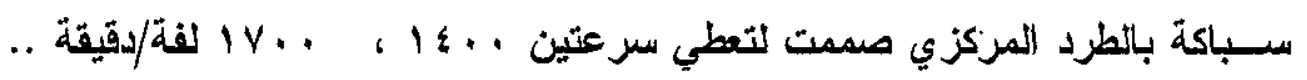

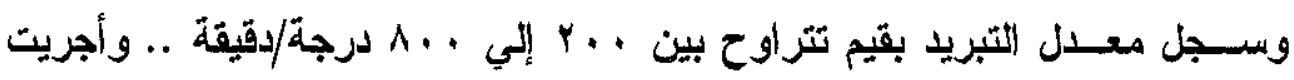

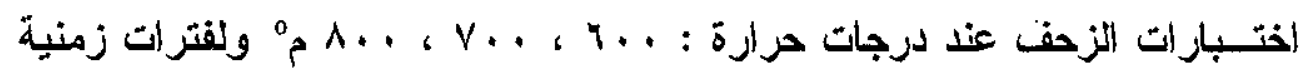

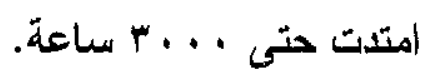

ويمكن إنجاز نتائج الاختبارات المعلية للصنب با \% كروم في النقاط الآتية: ا ـ تحسـنت مقاومسـة إنهيار الزحف مع زيادة معمل التبريد والأي يؤدي إلي

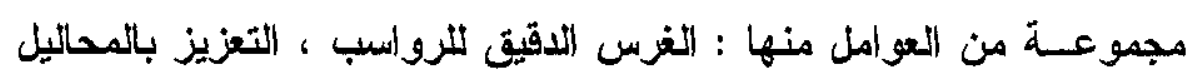

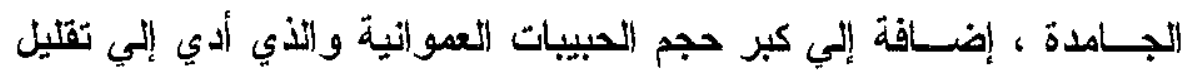
نشأة وسريان الثروخ الاقيقة. من المقترح مستقبلا دراسة تأثير إضافات كل من المولبدنم و الفاناديوم علي

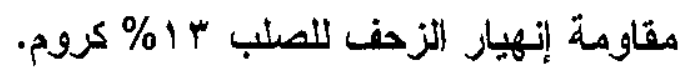

